\title{
NON-GENETIC FEATURES OF MILK YIELD TRAITS UNDER CUMULATIVE MONTHLY RECORDING SYSTEMS FLECKVIEH CATTLE. \\ Soliman, A. M. ${ }^{1}$; M. A. Mostafa ${ }^{2}$ and Sheren K. Genena ${ }^{3}$ \\ 1- Dept. of Animal Production, Fac. of Agric., Zagazig Univ., Egypt. \\ 2- Dept. of Animal Production, Fac. of Agric., Mansoura Univ., Egypt. \\ 3- Animal Production Res. Inst., Ministry of Agric., Dokki, Cairo, Egypt.
}

\begin{abstract}
Data were collected in two consecutive years $(1990,1991)$ and included 19000,27158 and 18999 records of three different periods of simulated cumulated 31 - $120\left(\mathrm{CMRS}_{1}\right), 61$ - $150\left(\mathrm{CMRS}_{2}\right)$ and 31 - $150\left(\mathrm{CMRS}_{3}\right)$ day of lactation for the first lactation in Fleckvieh cows from the Official Federation of Austrian Cattle Breeders (ZAR). $\quad$ Yields of 305-day (305-d MY) and cumulative milk (CMY), fat (305-d FY \& CFY), protein (305-d PY \& CPY), fat-plus-protein (305-d FPY \& CFPY) and percentage of protein yield/fat yield (305 POF \& CPOF\%) under $\mathrm{CMRS}_{1}$ up to $\mathrm{CMRS}_{3}$ were studied. The effects of calving year-season (CYS), age at first calving (AFC), days open (DO), the time from the first monthly test-day to next calving date (TFTNC) and sire on 305-day and cumulative milk traits (305-day MYT \& CMYT) were examined under various cumulative monthly recording systems (CMRS).

In general, the estimates of coefficient of variation (C.V) for 305-day MYT were $(16.5-18.6 \%)$ lower than the calculated CMYT $(20.4-22.9 \%)$, which reflected the large for CMYT. The estimates of C.V. for both FY and CFY were higher than all other 305-day MYT and CMYT. On the other side, the estimates of C.V. for both POF\% and CPOF\% under CMRS seemed to be similar.

The effects of sire were highly significant $(P<0.001)$ for all traits studied. Consequently, sire selection would lead to genetic improvement of milk traits. Calving year-season $(C Y S)$ affected significantly $(P<0.001)$ most of the studied traits under CMRS. Days open, age at first calving and the time from the first monthly test day to next calving date affected, significantly $(\mathrm{P}<0.05$ or $\mathrm{P}<0.01$ or $\mathrm{P}<0.001)$ all traits studied and should be considered in sire and cow evaluation program.
\end{abstract}

Keywords: Fleckvieh cattle, cumulative recording system, 305-day milk yield, cumulative milk yield traits.

\section{INTRODUCTION}

Improvement of milk production can be achieved by improving the environment and genetic factors. Both environmental and genetical factors contribute to variation in milk production. Therefore, the management of environment and genetic factors can result in improving many traits of milk production. In general, standardized 305-day milk yield of $1 \underline{\text { st }}$ lactation has been used in genetic evaluation of dairy sires. Furthermore, heifers did not complete $1 \underline{\text { st }}$ lactation or had lactation period shorter than 305-days have been used in the prediction of genetic merit. Therefore, estimating the effects of such factors on milk traits and correcting the data for their effects provides basic information for developing management and breeding programs of such traits. 
The milk recording system spread rapidly; and now plays an important role developed in advanced dairy industry. The main objectives of milk recording are: (1) to help the individual farmer to produce milk more efficiently and (2) to provide data for administrative, research, breeding and extension purposes. Actual decision regarding the choice of recording system depends on effective population size, number of sires to be tested, intensity of selection, availability of financial and physical facilities. On the other hand, in most developing countries milk recording is either non-existent or very rare (Lindstrom, 1977). Thus, test-day, cumulative monthly and other recording systems such as bimonthly, trimonthly could be used. The advantages of such systems are to reduce the cost, effort, time of recording timely culling and provide the basis to control herd management and genetic improvement. Very few studies have been concerned with some milk traits, i.e. 305-day fatplus-protein yield (FPY) and protein/fat yield as percent (POF\%). The main objective of the present study was to evaluate the influence of non-genetic factors on 305-day and calculated cumulative milk traits of Fleckvieh cattle in the $1^{\text {st }}$ lactation under cumulative monthly recording system.

\section{MATERIALS AND METHODS}

Data of milk yield traits of Austrian Fleckvieh cattle, collected by the Official Federation of Austrian Cattle Breeders (ZAR) in lower Austria was used in the present study. Records of cows calving in two successive years from January 1990 to September 1991 were used. Heifers and cows were artificially inseminated (Al) when heifers reached an average of $320 \mathrm{~kg}$ body weight and after the first observed heat in cows. Full-sib and sire-daughter matings were avoided. Details of the breeding policy and management for Austria Fleckvieh cattle were described by Hofinger et al. (1997).

Table (1) shows the single monthly test-day (TD) milk yield traits sample used for computing monthly and cumulative milk yield traits to three periods of cumulative milk traits: 1 st cumulative $31-120$ day (CMRS 1$), 2 \underline{\text { nd }}$ cumulative $61-150$ day $\left(\mathrm{CMRS}_{2}\right)$ and $3^{\text {rd }}$ cumulative $31-150$ day $\left(\mathrm{CMRS}_{3}\right)$.

Table (1): Equations used to calculate cumulative and 305-day milk yield traits (CMYT \& 305-day MYT).

\begin{tabular}{|c|c|}
\hline $\begin{array}{l}\text { Recording } \\
\text { system }\end{array}$ & Method of computation \\
\hline $\mathrm{Y}\left(\mathrm{CMRS}_{1}\right)$ & $\left.\left.\begin{array}{l}3 \\
{\left[\left(\sum_{i}=1\right.\right.}\end{array} D_{i} \times 30.5\right)\right]$ where: $i=1,2$ and $3,1=T_{2}, 2=T_{3}$ and $3=T$ \\
\hline $\mathrm{Y}\left(\mathrm{CMRS}_{2}\right)$ & $\begin{array}{l}3 \\
{\left[\left(\sum_{i=1} T_{i} \times 30.5\right)\right] \text { where: } i=1,2 \text { and } 3,1=T D_{3}, 2=T_{4} \text { and } 3=T_{5}}\end{array}$ \\
\hline $\mathrm{Y}\left(\mathrm{CMRS}_{3}\right)$ & $\left.\left.\begin{array}{l}4 \\
{[i=1}\end{array} \sum_{i} \times 30.5\right)\right]$ where: $i=1,2,3$ and $4,1=T D_{2}, 2=T D_{3}, 3=T_{4}$ and $4=T_{5}$ \\
\hline $\bar{Y}$ (305-day) & $\begin{array}{l}10 \\
{\left[\left(\sum_{i=1} T\right.\right.}\end{array}$ \\
\hline
\end{tabular}

Where TD = monthly test-day milk yield . 
As shown in Table (2), numbers of sires and total number of records for the three periods $\left(\mathrm{CMRS}_{1}, \mathrm{CMRS}_{2}\right.$ and $\left.\mathrm{CMRS}_{3}\right)$ were computed from the 1 st lactations records only.

Table (2): Distribution of sires and total number of records.

\begin{tabular}{|l|c|c|}
\hline \multicolumn{1}{|c|}{ Period } & No. of sires & Total No. of records \\
\hline $\mathrm{CMRS}_{1}(31-120$-day) & 1424 & 19000 \\
\hline $\mathrm{CMRS}_{2}(60-150$-day) & 1748 & 27158 \\
\hline $\mathrm{CMRS}_{3}(31-150$-day) & 1424 & 18999 \\
\hline
\end{tabular}

Studied traits were 305-day milk yield traits [milk yield (MY), fat yield (FY), protein yield (PY), fat-plus-protein yield (FPY) and percentage protein/fat yield (PY/FY\%)]. The same milk yield traits computed as cumulative [milk yield (CMY), fat yield (CFY), protein yield (CPY), fat-plusprotein yield (CFPY) and percentage-protein/fat (CPOF\%)] in the examined three periods.

Data were analyzed separately using the Least Squares Maximum Likelihood Mean Weighted (LSMLMW) computer program of Harvey (1990). Lactation records of milk traits were classified into seven groups according to the effects of calving year-season (CYS). The linear mixed model included the random effect of sire, the fixed effects of calving year-season (CYS), age at first calving (AFC), days open (DO) and time from the 1 st monthly test-day to next calving date (TFTNC) were regarded as partial linear $(\mathrm{L})$ and quadratic $(Q)$ regression coefficients of traits studied on these factors.

\section{RESULTS AND DISCUSSION}

Unadjusted means, standard deviations (S.D) and coefficients of variations (C.V\%) for 305-day and calculated cumulative milk yield traits (305day MYT and CMYT) under different cumulative monthly recording systems (CMRS) are presented in Table 3. Under CMRS 1 up to $\mathrm{CMRS}_{3}$ the means of 305-day MY in 1st lactation ranged from 4298 to $4339 \mathrm{~kg}$ fairly close to that obtained on the 1st lactation of Fleckvieh cattle in other studies. El-Sayed (1998) $4291 \mathrm{~kg}$ and Farghaly and Schleppi (2002) $4344 \mathrm{~kg}$ using the same breed. Meanwhile, the present estimates were higher than those reported by Strapak \& Strapakova (1997) 3636 kg and Genena (1998) 3789 kg of Fleckvieh cows. In contrast, the mean of 305-day MY is lower than that $(4716 \mathrm{~kg})$ found by Farghaly and Schleppi $(2001)$ by the 1 st lactation. Also, the means of 305-day FY, PY and FPY were 180, 143 and $323 \mathrm{~kg}$ for $\mathrm{CMRS}_{1}, \mathrm{CMRS}_{2}$ and $\mathrm{CMRS}_{3}$, respectively. They were close to estimates reported by El-Sayed (1998) 178, 141 and $320 \mathrm{~kg}$, respectively, but were higher than those found by Genena (1998) 154, 125 and $279 \mathrm{~kg}$, respectively, on the same breed under Austrian farm condition. While, the mean of 305day POF\% under different CMRS were similar (80\%) and similar also to the estimate of El-Sayed (1998) $80 \%$ and Genena (1998) $81.5 \%$ of Fleckvieh cows. Estimates of C.V\% for different CMRS ranged from 16.5 to $18.6 \%$ for 305-day MYT, higher than those of Soliman and Khalil (1993) 15.3 to $17.5 \%$, 
El-Sayed (1998) 11.5 to $13.0 \%$ and Genena (1998) 13.7 to $14.4 \%$ for the milk traits of 1st 100-day.

Table 3: Unadjusted means, standard deviation (SD) and coefficients of variation (CV\%) for 305-day and cumulative milk yield under different cumulative monthly recording systems (CMRS) of the first lactation in Fleckvieh cattle.

\begin{tabular}{|c|c|c|c|c|c|c|c|c|c|}
\hline \multirow[t]{2}{*}{ Traits $^{\star \star}$} & \multicolumn{3}{|c|}{$\mathrm{CMRS}_{1}$ (31 - 120 days) } & \multicolumn{3}{|c|}{$\mathrm{CMRS}_{2}$ (61 - 150 days) } & \multicolumn{3}{|c|}{$\mathrm{CMRS}_{3}$ (31 - 150 days) } \\
\hline & Mean & SD & CV\% & Mean & SD & CV\% & Mean & SD & CV\% \\
\hline \multicolumn{10}{|c|}{ 305-day milk traits (MT): } \\
\hline MY (kg) & 4339 & 796 & 16.5 & 4298 & 810 & 17.0 & 4339 & 796 & 16.5 \\
\hline FY (kg) & 180 & 37 & 18.2 & 179 & 37 & 18.6 & 180 & 37 & 18.2 \\
\hline PY (kg) & 143 & 27 & 17.3 & 142 & 28 & 17.7 & 143 & 27 & 17.3 \\
\hline FPY (kg) & 323 & 62 & 17.3 & 320 & 63 & 17.8 & 323 & 62 & 17.3 \\
\hline POF\% & 80 & 7 & 8.0 & 80 & 7 & 8.0 & 80 & 7 & 8.0 \\
\hline \multicolumn{10}{|c|}{ Cumulative milk traits (CMT): } \\
\hline CMY (kg) & 1007 & 326 & 22.2 & 1111 & 249 & 20.6 & 1426 & 310 & 20.4 \\
\hline CFY (kg) & 45 & 11 & 22.9 & 48 & 11 & 22.1 & 63 & 14 & 21.3 \\
\hline CPY (kg) & 36 & 8 & 22.2 & 39 & 9 & 21.4 & 50 & 11 & 20.6 \\
\hline CFPY (kg) & 81 & 19 & 22.3 & 87 & 19 & 21.0 & 113 & 24 & 20.7 \\
\hline CPOF\% & 80 & 8 & 9.0 & 81 & 8 & 9.0 & 81 & 8 & 9.0 \\
\hline
\end{tabular}

** MY = milk yield, FY = fat yield, $\quad$ PY = protein yield, PFY = fat and protein yield and POF\% = protein yield on fat yield $\%$,

$\mathrm{CMY}=$ cumulative milk yield, CFY = cumulative fat yield, $\quad C P Y=$ cumulative protein yield, CPFY = cumulative fat and protein yield. and CPOF $\%=$ cumulative protein yield on fat yield $\%$.

The means of calculated cumulative milk traits (CMY, CFY, CPY, CFPY and CPOF\%) under CMRS $1 \mathrm{CMRS}_{2}$ and $\mathrm{CMRS}_{3}$ ranged from 1007 to 1426 , from 45 to 63 , from 36 to 50 , from 81 to $113 \mathrm{~kg}$, and from 80 to $81 \%$, respectively, in the 1 st lactation. Also, under CMRS the estimates of C.V\% ranged from 20.4 to $22.9 \%$ for CMYT to be higher than the estimates of Soliman and Khalil (1993) from 14.5 to $16.4 \%$ and Zahed et al. (1997) from 14.4 to $14.8 \%$. While, the present results indicated that the estimates of C.V\% for CMY under $\mathrm{CMRS}_{1}$ were higher than those of $\mathrm{CMRS}_{2}$ and $\mathrm{CMRS}_{3}$, and they were lower than that reported by Soliman and Khalil (1993) Hamed and Soliman (1994) and Zahed et al. (1997) for the milk traits of 1st 100-day of Fleckvieh cattle. However, under CMRS the estimates of C.V\% for FY and CFY were found to be higher than those for PY and CPY as found by other studies of Soliman and Khalil, 1993; Zahed et al., 1997 and Genena, 1998. The estimates of C.V\% for 305-day MYT were lower than those for CMYT under CMRS, which was supported by the findings of Austrian studies (Soliman and Khalil, 1993).

While, the estimates of C.V\% for both POF\% and CPOF\% under different CMRS were nearly similar (around 8.0 to 9.0\%). They were lower than the ranges of 305-day MYT and CMYT under different CMRS. Similarly, Kennedy (1982) reported that yield traits showed more variability, as measured by C.V\% than did percentages traits. The observation of the examined systems in general, showed that the estimates of C.V\% under different CMRS (CMRS 1 to up $\mathrm{CMRS}_{3}$ ) for CMYT were higher than those estimates for 305-day MYT, which reflect the large individual variations in 
CMYT, consequently such higher C.V\% are indicative for improvement opportunities of these traits. Also, the means S.D, and C.V\% for 305-day MYT under $\mathrm{CMRS}_{1}$ and $\mathrm{CMRS}_{3}$ were similar, which may indicated similar accuracy of recording.

Effect of sire was highly significant $(P<0.001)$ for all traits studied as given in Table 3. Similar findings were reported in many studies (Wilmink, 1987 and 1988). Consequently, sire selection would lead to genetic improvement of milk yield traits. Effect of year-season of calving revealed that highly significant $(P<0.001)$ effects on all of the 305-day MYT and CMYT under the different system (CMRS 1 up to $\left.\mathrm{CMRS}_{3}\right)$. These results were in agreement with (e.g. Hamed and Soliman, 1994 and Zahed et al., 1997). This indicate the importance of including the effect of year-season of calving and their interaction for appropriate analysis to obtain unbiased estimates of sire evaluation in such traits. This means that adjustment of month, or season, and year of calving effects in bull evaluation for 305-day MYT and CMYT are necessary.Under the different examined systems (CMRS 1 up to $\mathrm{CMRS}_{3}$ ) a curvilinear $(P<0.05$ or $P<0.001)$ regression coefficients were obtained for both 305-day MY \& PY on age at 1st calving (AFC), except for PY under $\mathrm{CMRS}_{2}$, while coefficients were non-significant for other traits (FY \& FPY) (Table 4). Also, non-significant effect for CMYT on AFC was obtained except for $\mathrm{CMY} \& \mathrm{CPY}$ under $\mathrm{CMRS}_{2}$, or CMY only under $\mathrm{CMRS}_{3}$. Significant $(\mathrm{P}<$ 0.01 or $\mathrm{P}<0.001$ ) linear relationships were found for POF\% and CPOF\% on AFC under $\mathrm{CMRS}_{1}$ up to $\mathrm{CMRS}_{3}$. These results are in agreement with the findings of Soliman and Khalil, 1993 and Zahed et al. 1997. However, under the $\mathrm{CMRS}_{1}$ up to $\mathrm{CMRS}_{3}$ systems, a significant $(\mathrm{P}<0.05$ or $\mathrm{P}<0.01$ or $\mathrm{P}<$ 0.001 ) quadratic regressions coefficients were obtained for 305-day MYT \& CMYT on AFC, except POF\%, while CPOF\% under $\mathrm{CMRS}_{2}$ was significant $(P<0.05)$. These results reflect the increase of 305-day MYT \& CMYT under different CMRS with the advance of AFC. This mean that the adjustment of AFC effects are necessary to get more accurate sire or cow evaluation for 305-day MYT \& CMYT.

Results of Table 4 indicate significant $(P<0.05$ or $P<0.001)$ linear regression coefficients were of 305-day MYT on days open (DO) under different CMRS, except 305-day MY under both $\mathrm{CMRS}_{1}$ and $\mathrm{CMRS}_{3}$. However, non-significant quadratic regression coefficients were found for 305-day MYT under different CMRS, except under $\mathrm{CMRS}_{2}(\mathrm{P}<0.001)$ as shown in Table 4. Also, a significant $(P<0.001)$ linear regression coefficients were found for CMYT on DO under CMRS 1 up to $\mathrm{CMRS}_{3}$, except for CFY under $\mathrm{CMRS}_{3}$. Accordingly, as a same manner for age of first calving, correcting milk records for DO is recommended for accurate sire cow and evaluations. These results are in agreement with the findings of Zahed et al., 1997. However, non-significant $(P>0.05)$ relationships in linear and quadratic manner were obtained for both $\mathrm{POF} \%$ and $\mathrm{CPOF} \%$ on DO under different CMRS except linear CPOF\% $(P<0.001)$ under $C M R S_{1}$ and $C M R S_{2}$, quadratic under $\mathrm{CMRS}_{2}(\mathrm{P}<0.05)$. 
Soliman, A. M. et al.

T4

8732 
While, a significant $(P<0.05)$ relationship in quadratic manner were evidenced for CMYT on DO; except CPOF\% (Oltenacu et al., 1980).

Significant $(P<0.05$ or $P<0.001)$ linear relationships were found for both 305-day MYT \& CMYT on time from the first test-day to next calving date (TFTNC) under different CMRS, except that with POF\%, and CPOF\% under $\mathrm{CMRS}_{2}$ and $\mathrm{CMRS}_{3}$ (Table 4). However, a significant relationship ( $\mathrm{P}<$ 0.05 or $\mathrm{P}<0.01$ or $\mathrm{P}<0.001$ ) in quadratic fashion were evidence for 305 -day MYT \& CMYT on TFTNC under CMRS 1 up to $\mathrm{CMRS}_{3}$, except CPY under both $\mathrm{CMRS}_{1} \& \mathrm{CMRS}_{3}$ and CFPY under $\mathrm{CMRS}_{1}$. On the other hand, significant relationship $(P<0.05)$ in quadratic manner was evidenced for CPOF\% on TFTNC under different CMRS, except under $\mathrm{CMRS}_{3}$, while they were non-significant $(P>0.05)$ for CPOF\% in different CMRS as shown in Table 4. Therefore, the effect of TFTNC on 305-day MYT \& CMYT must be considered in any programme for sire and cow evaluations for these traits.

\section{CONCLUISION}

The present results indicated that $\mathrm{CMRS}_{2}$ (which consider the period 61 - 150 day) of 305-day MYT and CMYT yielded higher C.V\%. Like wise, in all the examined systems, the cumulative milk yield traits (CMYT) showed higher C.V\% than 305-day milk yield traits (305-day MYT) reflecting the presences of good opportunity to improve these traits.

The obtained significant effects $(P<0.001)$ of year-season of calving (YSC) on all studied traits under different CMRS recommend the inclusion of this factor in any programme of sire evaluation for 305-day MYT and CMYT. In the same time, the linear and quadratic $(P<0.05$ or $P<0.01$ or $P<0.001)$ regression coefficients of both 305-day MYT and CMYT. for each CMRS on age at $1 \underline{\text { st }}$ calving (AFC), days open (DO) and time from the 1 st test-day to next calving date (TFTNC) indicate the importance of correcting the milk records for these factors, to provide accurate information for genetic improvement of such traits in breeding programs.

\section{ACKNOWLEGEMENT}

We gratefully acknowledge the Official Federation of Austrian Cattle Breeders (ZAR) for supplying the data.

\section{REFERENCES}

El-Sayed, S.I.M. (1998). Inheritance of somatic cell count and its genetic relationship with productive traits in dairy cattle. M.Sc. Thesis, Fac. of Agric., Zagazig Univ., Egypt, pp. 215.

Farghaly, H.M. and Y. Schleppi (2001). Genetic parameters of persistency and its correlation with partial total and peak milk yield on Fleckvieh cow. $2^{\text {nd }}$ Inter. Conf. on Animal Production and Health in Semi. Arib Areas, 1: $267-278$.

Farghaly, H.M. and Y. Schleppi (2002). New mathematical description of persistency by determining critical biological points in lactation curve in Fleckvieh breed. XXII World Buidatrics Congress (Germany). 
Genena, Shereen K. (1998). Some genetic aspects of productive and reproductive traits in dairy cattle. Thesis Fac. of Agric., Zagazig Univ., Egypt.

Harvey, W.R. (1990). User's Guide for LSMLMW. Mixed model least squares and maximum likelihood computer program. PC-Version 2, Ohio State University Columbus, U.S.A., (Mimeograph).

Hofinger, M.; J. Wiesbock and E. Potucek (1997). Cattle breeding in Austria. Zentrale Arbeitsgemeinschaft. Osteereichischer Rinderzuchter, 1200 Wein, Austria.

Kennedy, B.W. (1982). Reduction fat in milk and dairy products by breeding. J. Dairy Sci., 65: $443-449$.

Lindstrom, U.B. (1977). Milk recording in developing countries. Animal Production and Health Paper 1. Food and Agriculture Organization of the United Nations Rome (C) FAO, 1977.

Oltenacu, P.A.; T.R. Rounsaville; R.A. Milligan and R.L. Hintz (1980). Relationship between days open and cumulative milk yield at various intervals parturition for high and low productions cows. J. Dairy Sci. 63: $1317-1321$.

Soliman, A.M. and M.H. Kahlil (1993). Estimation of genetic parameters for single and composite milk traits in Fleckvieh cattle and their uses in programmers of early selection. Egypt J. Anim. Prod., 30: 2137.

Hamed, M.K. and A.M. Soliman (1994). Genetic aspects of fertility, interval and milk traits for the first three lactations in Braunvieh cows. Egypt. J. Anim. Prod., 31: $251-280$.

Strapak, P. and E. Strapakova (1997). Milk productions of imported Fleckvieh cows. Biotehnologija U-stocanstvu, 13(5/6) 281 - 288. (A.B.A., 1998, N6).

Wilmink, J.B.M. (1987). Efficiency of selection for different cumulative milk, fat and protein yields in first lactation. Livest. Prod. Sci.,17: 211-224.

Wilmink, J.B.M. (1988). Effects of incomplete records on genetic parameters among cumulative yields in first lactation and on extension of part lactation. Livest. Prod. Sci., 18: $19-34$.

Zahed, S.M., M.H. Khalil and A.M. Soliman (1997). Comparison between efficiency of part-and complete lactation records in progeny testing Fleckvieh bulls. Egypt. J. Anim. Prod., 34(1): $11-26$. 


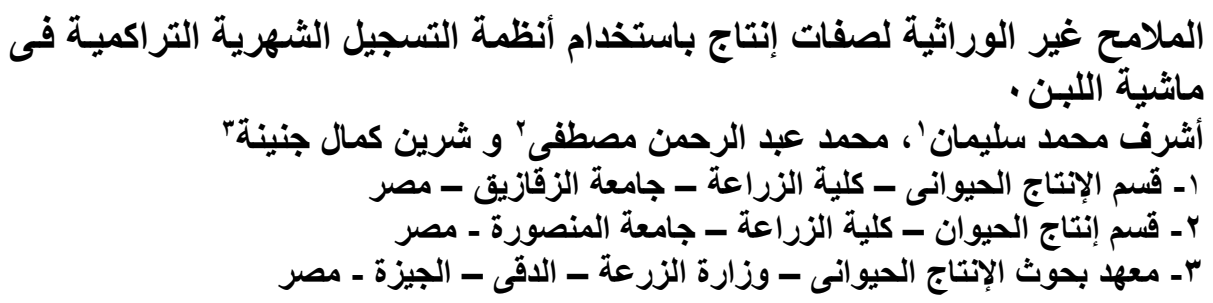

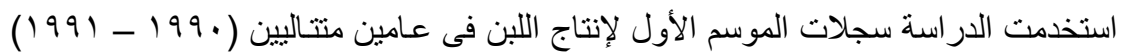

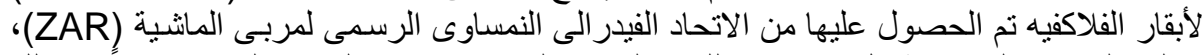

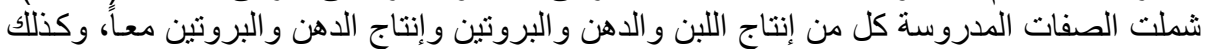

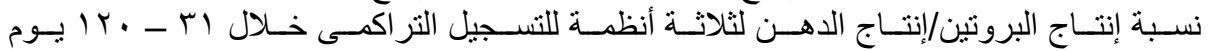
(CMRS 1 (CMRS

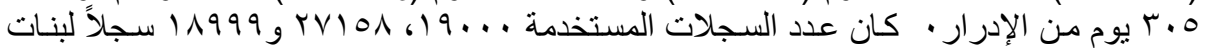

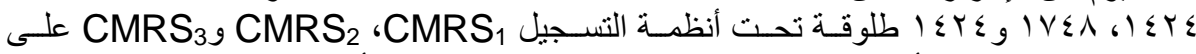

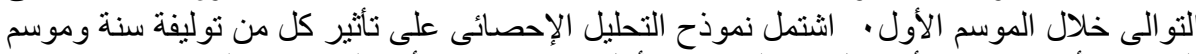

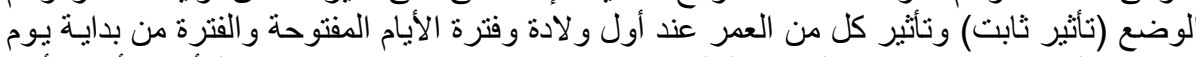

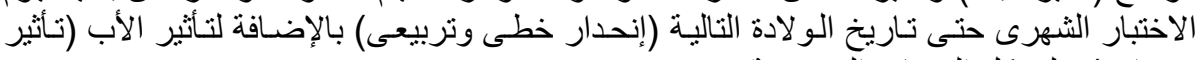
عشو ائى) على كل الصفات النقات المدروسة.

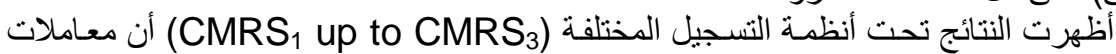

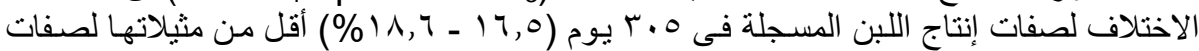

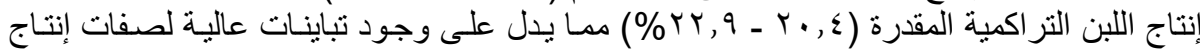

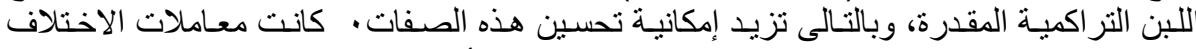

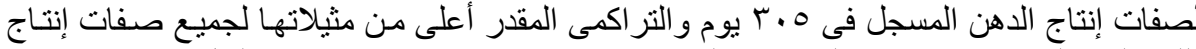

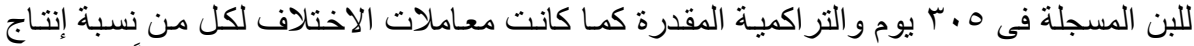

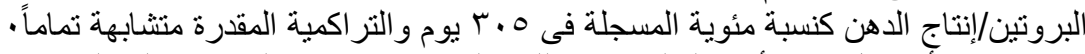

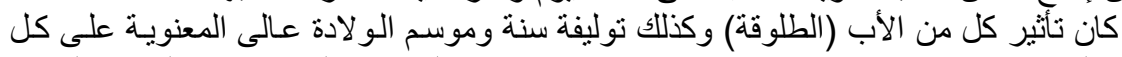

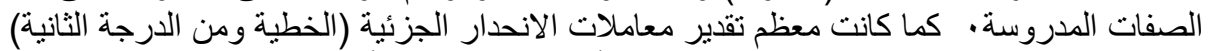

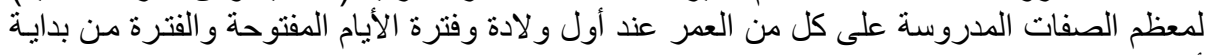
أول يوم اختبار حتى تاريخ الو لادة التالية معنوية.

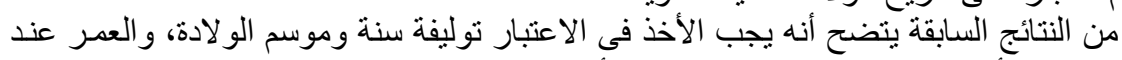

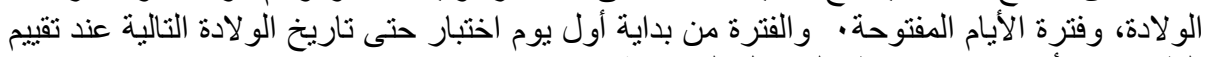

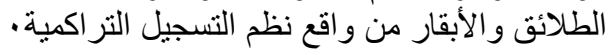



Table 4: least squares analyses of variance for 305-day yield traits and cumulative milk yield traits under different cumulative recording systems (CMRS) of Fleckvieh cattle.

\begin{tabular}{|c|c|c|c|c|c|c|c|c|c|c|c|}
\hline \multirow[b]{2}{*}{ S.o.v. } & \multirow[b]{2}{*}{ d.f } & \multicolumn{5}{|c|}{ 305-day milk traits } & \multicolumn{5}{|c|}{ Cumulative milk traits } \\
\hline & & MY (kg) & FY (kg) & PY (kg) & FPY (kg) & POF\% & CMY (kg) & CFY (kg) & CPY (kg) & CFPY (kg) & CPOF\% \\
\hline \multicolumn{12}{|c|}{ CMRS $_{1}$ (31 - 120 days) } \\
\hline Sire & 1423 & $2.8^{\star \star \star}$ & $3.2^{* \star *}$ & $2.8^{\star \star \star}$ & $3.0^{\star \star \star}$ & $3.2^{\star * *}$ & $2.2^{\star \star \star}$ & $2.3^{\star \star *}$ & $2.1^{\star \star *}$ & $2.3^{\star \star *}$ & $2.3^{\star \star \star}$ \\
\hline YSC & 6 & $45.9^{\star * *}$ & $19.9^{* \star *}$ & $21.9^{* \star *}$ & $21.3^{\star \star \star}$ & $12.0^{\star \star \star}$ & $32.5^{\star \star \star}$ & $13.9^{\star \star \star}$ & $19.3^{\star \star \star}$ & $15.8^{\star \star \star}$ & $29.2^{\star \star \star}$ \\
\hline \multicolumn{12}{|c|}{ Partial regression on: } \\
\hline AFC (L) & 1 & $25.6^{\star \star \star}$ & $0.4^{\mathrm{NS}}$ & $4.1^{\mathrm{NS}}$ & $1.6^{\mathrm{NS}}$ & $9.0^{\star *}$ & $1.2^{\mathrm{NS}}$ & $2.6^{\mathrm{NS}}$ & $0.1^{\mathrm{NS}}$ & $1.2^{\mathrm{NS}}$ & $8.4^{\star \star}$ \\
\hline (Q) & 1 & $14.0^{\star \star \star \star}$ & $6.2^{\star}$ & $8.6^{\star *}$ & $7.6^{\star *}$ & $0.5^{\mathrm{NS}}$ & $17.4^{\star \star \star}$ & $10.8^{\star *}$ & $15.5^{\star * *}$ & $13.3^{\star * *}$ & $2.7^{\mathrm{NS}}$ \\
\hline (L) & 1 & $1.7^{\mathrm{NS}}$ & $3.0^{*}$ & $4.5^{\star}$ & $3.8^{*}$ & $0.0^{\mathrm{NS}}$ & $99.2^{\star \star \star}$ & $6.8^{\star \star}$ & $33.7^{* \star \star}$ & $16.8^{\star \star \star}$ & $55.5^{\star \star \star}$ \\
\hline (Q) & 1 & $1.8^{\mathrm{NS}}$ & $1.7^{\mathrm{NS}}$ & $2.5^{\mathrm{NS}}$ & $2.2^{\mathrm{NS}}$ & $0.1^{\mathrm{NS}}$ & $0.4^{\mathrm{NS}}$ & $0.3^{\mathrm{NS}}$ & $0.4^{\mathrm{NS}}$ & $0.4^{\mathrm{NS}}$ & $0.1^{\mathrm{NS}}$ \\
\hline TFTNC (L) & 1 & $249.3^{\star * *}$ & $218.9^{\star \star *}$ & $252.6^{* \star *}$ & $145.5^{\star \star \star}$ & $0.3^{\mathrm{NS}}$ & $311.9^{\star \star *}$ & $76.4^{\star \star \star}$ & $95.6^{\star \star \star}$ & $88.5^{\star \star \star}$ & $2.8^{\star}$ \\
\hline (Q) & 1 & $48.4^{\star \star \star}$ & $38.4^{\star \star *}$ & $50.3^{\star * *}$ & $45.6^{\star \star}$ & $1.0^{\mathrm{NS}}$ & $7.4^{\star *}$ & $3.0^{*}$ & $1.1^{\mathrm{NS}}$ & $2.2^{\mathrm{NS}}$ & $3.6^{*}$ \\
\hline Remainder & 17564 & 513064 & 1073 & 612 & 3139 & 0.004 & 48614 & 106 & 64 & 319 & 0.006 \\
\hline \multicolumn{12}{|c|}{ CMRS $_{2}$ (61 - 150 days): } \\
\hline Sire & 1747 & $3.3^{\star \star \star}$ & $3.6^{\star \star \star}$ & $3.3^{\star \star \star}$ & $3.5^{\star \star \star}$ & $3.6^{\star \star \star}$ & $2.6^{\star \star \star}$ & $2.8^{\star \star \star}$ & $2.6^{\star \star \star}$ & $2.7^{\star \star \star}$ & $2.8^{\star \star \star}$ \\
\hline YSC & 6 & $67.4^{\star \star \star}$ & $30.1^{* * *}$ & $31.2^{* * *}$ & $31.5^{\star \star \star}$ & $13.6^{\star \star \star}$ & $88.1^{\star \star \star}$ & $31.6^{\star * \star}$ & $31.8^{* \star *}$ & $31.4^{\star \star \star}$ & $39.4^{\star \star *}$ \\
\hline \multicolumn{12}{|c|}{ Regression on: } \\
\hline AFC (L) & 1 & $26.3^{\star \star \star}$ & $0.0^{\mathrm{NS}}$ & $2.3^{\mathrm{NS}}$ & $0.4^{\mathrm{NS}}$ & $9.6^{* *}$ & $18.2^{* * *}$ & $0.1^{\mathrm{NS}}$ & $4.1^{*}$ & $1.2^{\mathrm{NS}}$ & $12.1^{\star \star \star}$ \\
\hline (Q) & 1 & $19.8^{\star \star *}$ & $7.8^{\star \star}$ & $12.1^{\text {***}}$ & $10.0^{\star \star}$ & $1.0^{\mathrm{NS}}$ & $26.3^{\star \star *}$ & $15.1^{\star \star \star}$ & $22.0^{\star \star *}$ & $10.9^{* * *}$ & $3.2^{*}$ \\
\hline (L) & 1 & $54.8^{\star \star \star}$ & $43.6^{\star \star \star *}$ & $47.5^{\star \star \star}$ & $47.6^{\star \star \star}$ & $0.1^{\mathrm{NS}}$ & $73.5^{\star \star \star}$ & $19.9^{* \star \star}$ & $60.9^{\star \star \star}$ & $36.9^{\star \star \star}$ & $51.4^{\star \star \star}$ \\
\hline (Q) & 1 & $15.1^{\star \star \star}$ & $8.8^{\star *}$ & $12.7^{\star \star \star}$ & $10.9^{\star \star \star}$ & $1.0^{\mathrm{NS}}$ & $0.3^{\mathrm{NS}}$ & $0.3^{\mathrm{NS}}$ & $2.7^{\mathrm{NS}}$ & $1.1^{\mathrm{NS}}$ & $5.7^{\star}$ \\
\hline TFTNC(L) & 1 & $100.9^{\star * *}$ & $82.7^{\star \star *}$ & $95.5^{\star \star *}$ & $92.7^{\star \star \star}$ & $0.1^{\mathrm{NS}}$ & $673.2^{* \star *}$ & $213.2^{\star \star *}$ & $249.3^{\star \star \star}$ & $240.6^{\star \star \star}$ & $1.3^{\mathrm{NS}}$ \\
\hline (Q) & 1 & $4.2^{*}$ & $5.3^{*}$ & $5.0^{*}$ & $5.5^{\star}$ & $0.1^{\mathrm{NS}}$ & $11.6^{* * *}$ & $3.6^{*}$ & $6.7^{\star *}$ & $5.1^{*}$ & $2.9^{*}$ \\
\hline Remainder & 25398 & 529349 & 1112 & 631 & 3252 & 0.004 & 51270 & 108 & 66 & 326 & 0.006 \\
\hline \multicolumn{12}{|c|}{ CMRS $_{2}$ (31 - 150 days) } \\
\hline Sire & 1423 & $2.8^{\star \star \star}$ & $3.2^{\star \star \star}$ & $2.8^{\star \star \star}$ & $3.0^{\star \star \star}$ & $3.2^{\star \star \star}$ & $2.3^{\star \star \star}$ & $2.5^{\star \star \star}$ & $2.3^{\star \star \star}$ & $2.4^{\star \star \star}$ & $2.6^{\star \star \star}$ \\
\hline YSC & 6 & $45.9^{\star \star \star *}$ & $19.8^{* * *}$ & $21.9^{\star \star \star}$ & $21.3^{* \star \star}$ & $12.0^{* \star \star}$ & $40.7^{\star \star \star}$ & $16.9^{\star \star \star}$ & $19.9^{* \star \star}$ & $17.7^{* \star \star}$ & $3.9^{\star \star \star}$ \\
\hline \multicolumn{12}{|c|}{ Partial regression on: } \\
\hline AFC (L) & 1 & $25.6^{* * *}$ & $0.4^{\mathrm{NS}}$ & $4.1^{*}$ & $1.6^{\mathrm{NS}}$ & $8.9^{\star \star}$ & $4.4^{\star}$ & $0.9^{\mathrm{NS}}$ & $0.2^{\mathrm{NS}}$ & $0.1^{\mathrm{NS}}$ & $10.2^{* *}$ \\
\hline (Q) & 1 & $14.0^{\star \star \star \star}$ & $6.2^{*}$ & $8.6^{* \star}$ & $7.6^{\star \star}$ & $0.5^{\mathrm{NS}}$ & $17.9^{\star * *}$ & $11.2^{\star \star *}$ & $16.4^{* * *}$ & $13.9^{\star \star \star}$ & $2.4^{\mathrm{NS}}$ \\
\hline (L) & 1 & $1.7^{\mathrm{NS}}$ & $3.0^{*}$ & $4.4^{*}$ & $3.8^{*}$ & $0.0^{\mathrm{NS}}$ & $22.3^{\star \star \star}$ & $2.1^{\mathrm{NS}}$ & $16.4^{\star \star \star}$ & $7.0^{\star \star}$ & $37.1^{\star \star \star}$ \\
\hline (Q) & 1 & $1.7^{\mathrm{NS}}$ & $1.7^{\mathrm{NS}}$ & $2.4^{\mathrm{NS}}$ & $2.1^{\mathrm{NS}}$ & $0.0^{\mathrm{NS}}$ & $0.5^{\mathrm{NS}}$ & $0.8^{\mathrm{NS}}$ & $0.8^{\mathrm{NS}}$ & $0.8^{\mathrm{NS}}$ & $0.1^{\mathrm{NS}}$ \\
\hline TFTNC (L) & 1 & $249.3^{\star \star \star}$ & $218.9^{\star \star \star}$ & $252.6^{\star \star \star}$ & $245.5^{\star \star \star}$ & $0.3^{\mathrm{NS}}$ & $263.4^{\star \star \star}$ & $61.2^{\star \star \star}$ & $72.3^{\star \star \star}$ & $69.1^{\star \star \star}$ & $0.9^{\mathrm{NS}}$ \\
\hline (Q) & 1 & $38.4^{* \star *}$ & $38.4^{\star \star \star}$ & $50.3^{* \star *}$ & $45.6^{\star \star \star}$ & $1.0^{\mathrm{NS}}$ & $8.8^{* *}$ & $3.6^{*}$ & $2.2^{\mathrm{NS}}$ & $3.1^{*}$ & $1.9^{\mathrm{NS}}$ \\
\hline Remainder & 17564 & 513091 & 1073 & 612 & 3139 & 0.004 & 82172 & 175 & 106 & 529 & 0.005 \\
\hline $\begin{array}{l}{ }^{*} \text { Significa } \\
\text { YSC: Year }\end{array}$ & & & $\begin{array}{l}\text { Signific } \\
\text { AFC: A }\end{array}$ & & & $\begin{array}{c}\text { *** } \mathrm{Sig} \\
\text { DO }\end{array}$ & $\begin{array}{l}\text { ant at } P< \\
\text { s open }\end{array}$ & 1 & NS $n$ & significan & $\mathrm{t} P>0.05$ \\
\hline
\end{tabular}

